\section{Jolly Sahni ${ }^{1}$}

\title{
QUALITY OF WORK LIFE (QWL), QUALITY OF LIFE (QOL) AND HAPPINESS: EXPLORING THE LINKAGES FOR MILLENNIAL WORKFORCE
}

\begin{abstract}
Although, quality of work life $(Q W L)$ and quality of life $(Q o L)$ has attracted the interest of practitioners and academic researchers alike, yet, the link of QWL and QoL with happiness remains under investigated, in particular, for the millennial workforce. Happiness has been considered as an important requisite of living a fulfilled and meaningful life. The purpose of this study is to uncover the complex linkages among three important factors; quality of work life, quality of life and happiness. In addition, the study identifies factors which affect happiness of millennial workforce at work. The study adopts cross-sectional survey approach. Data was collected from a random sample of 210 female employees working in the banking sector of Saudi Arabia. Data was analyzed with the help of SPSS AMOS 25.0. The findings were significant and advances the current knowledge and literature on the subject. This would also be a pioneer study in exploring the complex linkage among $Q W l, Q o L$ and happiness for millennial at work.
\end{abstract}

Keywords: Quality of work life ( $Q W L)$, Quality of life ( $Q \circ L)$, Happiness at work (HAW), Millennial workforce

\section{Introduction}

Happiness is considered as the ultimate goal of human beings (Michalos, 2006), which is simple yet difficult to achieve. The significance of having happy citizens is now being realized in many countries. UAE (United Arab Emirates) has recently appointed a Minister of state of Happiness \& Wennbeing, while Bhutan has been the first country to measure happiness in form of gross national happiness (GNH). Happiness is a psychological concept which is gaining importance in the human resource management at organizations. As employees are the backbone of organizations, therefore, must be positive and happy at work. Happiness is often used as an index for quality of life (Tay et al., 2015). Several authors have attempted to define happiness; some define it as a 'life satisfaction' while others consider it as a dominance of positive feelings over the negative emotions while the rest consider it as a virtue (Diener and Diener, 1996). Though difficult to define, it is the "central concern for humanity (Kashdan et al., 2008). More importantly, for organizations, happiness of employees mean

\footnotetext{
${ }^{1}$ Corresponding author: Jolly Sahni Email: jsahni@psu.edu.sa
} 
higher productivity and long-term positivity at the workplace. Happiness at work can possibility be influenced by many factors at work place, for example, career development, workload, infrastructure or salary (Mazuki et al., 2017). Quality of Life (QoL) is the aspect of life which can have psychological, physical and health-related meanings (Fallowfield, 1990). However, quality of life does not reflect happiness of individual, as suggested by Veenhoven (2001), Quality of life and happiness are very different from each other.

Studies on quality of work life can be traced in the history as early as 1970, when Walton introduced the concept in an International conference. Quality of work life (QWL) can be the means to achieve happiness and thereby lead to satisfactory quality of life. Therefore, all three concepts are intertwined; one leads to other and vice-versa. Past studies have established the strong connection between happiness and quality of life (Moccia, 2016). Similarly, the concept of Quality of work life is established as a prerequisite for high performing and engaged employees at workplace (Gayathiri et al., 2013; Sahni, 2017, Kim et al., 2017; Sahni 2019). Researchers have also attempted to explore the relationship between QWL and QoL (Elizur \& Shye, 1990; Narehan et al., 2014).

Past studies have been conducted to examine the quality of work life, quality of life and happiness in silo and generally and no focussed studies have been done on what causes happiness in the young blood (Millennial) of organization. Also, the role of quality of work life in influencing happiness of millennial workforce is under investigated. For Saudi Arabia, which is a growing economy, the workforce has more than fifty percent of millennial. Millennial makeup an important part of the workforce not only in Saudi but it is suggested that the global workforce will make up over a third of the Millennial by 2020 (ManpowerGroupFirm, 2016). This generation of workforce is uniquely characterized with positive work attitudes, multitasking and low tolerance of stress Accordingly, the focus of this study is on millennial employees of banking Industry of Saudi Arabia.

Also, recent studies have recommended further research in the area of positive attitudes such as happiness at work (Ugwu et al., 2014). Particularly, in the banking industry the promotion of happiness at work becomes essential (Schaufeli \& Bakker, 2004). Hackman (2009) also highlighted that the concept of happiness needs to be studied in relation to work related factors which promote happiness at work. Therefore, to fill the aforementioned gaps and to explore the complex relationship between QWL, QOL and happiness, particularly for the millennial generation, the present study is undertaken.

\section{Summary of relevant Literature}

Quality of work life and happiness have been studied in the past through an interdisciplinary lense. Quality of life is a much broader concept which might be associated with QWL and happiness. All these three concepts have attracted researchers and practitioners from a number of fields for example scholars from management, psychology, social science and so on. This section presents a brief summary of relevant past studies on these concepts.

Happiness at work (HAW) has been studied vastly by management scholars (Joaquim Araújo de Azevedo et al., 2013; Gulyani \& Sharma, 2018). Moreover, there has been an increase in the study of positive psychology in the recent decade (Xanthopoulou et al., 2012), which is mainly due to the reason that the positive attitude leads to better outcome for employees and organizations (Guest, 2017). According to Fisher (2010), happiness at work is a broad measure which includes positive attitudes of employees at work. It has been defined as "a mindset which enables action to maximize 
performance and achieve potential" by Pryce-Jones \& Lindsay, (2014, p.131). The central cause of happiness in organizations are generally associated with the organization itself and the job context. The causal relation of HAW with organizational outcomes becomes imperative to study (Lyubomirsky et al., 2005). HAW is closely related to the concepts of work engagement and burnout which generally predicts the satisfaction among employees (Bakker and Oerlemans, 2016). Recently, an interesting article on "Oh, what Happiness! Finding joy and purpose through work" by Joan Marques (2017) attracted readers as she writes interesting facts about happiness and how "we have learned to toss happiness on the heap of impossibilities in our lives today" (p.1). Happiness at work have a positive effect in terms of higher productivity, lower turnover of employees which leads to overall organizational performance (De Wall, 2018). Moreover, Pryce-Jones \& Lindsay (2014) suggests that the unhappy employees spend about only 40 percent of their time on task, which is a state of concern for organizations.

The term Quality of work life (QWL) refers to the favourableness or non-favourableness of a total job environment for the employees. It can be any conscious effort for improving the working conditions and has a strong focus on providing a work environment conducive to satisfy individual needs. It mainly includes aspects of work-related life such as wages and working hours, work environment, benefits and services, career prospects and human relations, which are related to worker satisfaction and motivation. Early researchers have performed an imperative role in laying the foundation of the concept of QWL (Walton, 1973; Mirvis and Lawler, 1984). Similarly, it is widely recognized that a significant approach of quality of work life affects jobs and work environments that impacts most strongly the job satisfaction, job performance, and life-long well being of employees (Seashore, 1975; Kalra and
Ghosh, 1984).

Sirgy et al., (2001) proposed that higher levels of QWL results in higher satisfaction among employees. Moreover, QWL has been established as a determinant of higher performance in employees and organizations (Nayak \& Sahoo, 2015; Buchanan \& McCalman, 2018)

Yet another related concept is of Quality of Life (QOL). As QOL has interdisciplinary nature, it has attracted economists, sociologists, healthcare professionals and social science researchers (Sirgy et al., 2006: Dunning et al., 2008), which resulted in many definitions and meanings for QOL in the past studies. According to Gregory et al., (2009), QOL includes the environment, education, physical and mental health, leisure time and social belongingness. QOL has been examined through mainly two approaches in the past studies (Diener \& Suh, 1997). The first one is objective which includes lifestyle, working conditions or state of health, while the second one is subjective, which includes largely the perception of people in gauging their living conditions (Noll, 2002). According to Inoguchi \& Fujii (2012) this notion of QOL with objective approach represents the conditions under which people live and subjective approach is basically how people feel about these conditions. The dynamic nature of QOL has been studied in several countries as a social phenomenon; for example, Portugal (Sousa Gomes et al., 2010) Scandinavian countries (Erikson, 1993), Germany (Hoebel et al., 2013), Bhutan (Ura \& Galay, 2004; Tideman, 2016).

Past studies have associated QoL with happiness. According to Veenhoven (1991) happiness is the degree to which an individual judges the overall quality of his life favorably (p.2). Similarly, other researchers have linked QOL with happiness directly, QOL is considered as a prerequisite for happiness. Therefore, QOL and happiness are related in different ways. 
However, QWL has not been explored in this context yet. Therefor, it is hypothesized that:

H1. Quality of Work life (QWL), Quality of Life (QoL) and Happiness at Work (HAW) are positively related.

H2. General Well-Being (GWB-subscale of $Q W L)$ is positively related to Happiness of Millennial female work force.

H3. Home-Work Interface (HWI-subscale of QWL) is positively related to Happiness of Millennial female work force.

H4. Job and Career Satisfaction (JCSsubscale of $Q W L$ ) is positively related to Happiness of Millennial female work force.

H5. Control at Work (CAW-subscale of $Q W L)$ is positively related to Happiness of Millennial female work force.

H6. Working Conditions (WCS-subscale of $Q W L)$ is positively related to Happiness of Millennial female work force.

H7. Stress at Work (SAW-subscale of $Q W L$ ) is negatively related to Happiness of Millennial female work force.

\section{Methods}

The study is an explanatory and descriptive study which adopts a cross-sectional survey approach. 500 surveys were sent through electronic form to the female employees working in different banks of Riyadh, Saudi Arabia. 210 filled and completed data sets were received and considered for data analysis. The sample consisted of $95 \%$ females under the age of 40 years. $42 \%$ of them were married while $70 \%$ had a master's degree, $25 \%$ had a bachelor's degree as highest qualification.

The questionnaire had four sections; first was on demographic information of respondents, second section considered the quality of work life while section three assessed their happiness at work and the last section measured the quality of life of the respondents. The scales adopted for this study were WRQoL (work related quality of work life) with 24 items and Orientation to Happiness with 9 items and QoL (Quality of Life) scale with 15-items. All items were measured on a five-point likert scale. In addition, respondents were asked few openended questions about the factors at workplace that make them happy. This was analysed using content analysis and grouped in different themes emerging from the similar responses.

Data was analysed with the help of SPSS AMOS 25.0. Data sets were first checked for the missing values and normality of all variables, then confirmatory factor analysis was conducted to test the psychometric properties of the scales. Further, content validity was checked through a proper review of literature, in addition to a feedback on the scales by the expert opinion Finally, Structured equation modelling was applied to test the relationships among study variables.

\section{Findings and Discussion}

The psychometric properties of the three scales used in this study was analysed. Descriptive statistics were then calculated. The results of CFA were significant; all factor loading were above the acceptable limit of 0.50 . The p-value of chi-square statistics was also below the significance level (0.05). The model fit indicators were within the range, $\mathrm{CMIN}=1.79, \mathrm{CFI}=0.98$ and RMSEA $=0.047$.

Table 1 shows the composite reliabilities, mean scores and inter-variable correlations coefficients. The reliabilities of measures range from 0.67 to 0.89 . The results indicate that millennial employees are more satisfied with their quality of work life (4.33 points) and less satisfied with their quality of life ( 3.78 points). The findings suggest a positive and significant association among the three constructs, however, the strongest correlation was seen in QWL and 


\section{Interinational Cuality Conference 1 !}

HAW ( $\mathrm{r}=0.78 ; \mathrm{p}<0.01)$, indicating that the quality of work life may have a strong influence on happiness of employee at work. The weakest, yet significant association was found in between quality of life and happiness at work ( $\mathrm{r}=0.394 ; \mathrm{p}<0.01)$, whereas the relationship between quality of life and quality of work life was found to be average $(\mathrm{r}=0.482 ; \mathrm{p}<0.05)$. The findings support hypothesis 1 . Therefore, to further investigate and to test the relationships and significant influence of all variable of QWL on happiness at work, regression estimates were calculated.

Table. 2 presents the correlations between the sub-scales of QWL and happiness at work. The strongest association of happiness at work was found to be with career satisfaction $(\mathrm{r}=0.590 ; \mathrm{p}<0.01)$ and general well-being $(\mathrm{r}=0.601 ; \mathrm{p}<0.01)$. However, the association of happiness at work was found to be weak with three sub factors of QWL; home-work interface $(\mathrm{r}=0.420 ; \mathrm{p}<0.05)$, control at work $(\mathrm{r}=0.411 ; \mathrm{p}<0.01)$ and working condition $(\mathrm{r}=0.486 ; \mathrm{p}<0.01)$. As predicted, happiness was found to be negatively associated with stress at work $(\mathrm{r}=-$ $0.67 ; \mathrm{p}<0.01)$.

Table 1. Mean, Standard Deviation, Reliabilities and Inter-correlations among constructs of the study

\begin{tabular}{|l|l|l|l|l|l|}
\hline Variable & Mean & SD & $\mathbf{1}$ & $\mathbf{2}$ & $\mathbf{3}$ \\
\hline $\begin{array}{l}\text { 1. Quality } \\
\text { of Work } \\
\text { life }\end{array}$ & 4.33 & 0.93 & $(0.67)$ & & \\
\hline $\begin{array}{l}\text { 2. Quality } \\
\text { of Life }\end{array}$ & 3.78 & 0.70 & $.482^{* *}$ & $(0.78)$ & \\
\hline $\begin{array}{l}3 . \\
\text { Happiness } \\
\text { at work }\end{array}$ & 4.20 & 1.17 & $.781^{*}$ & $.394^{*}$ & $\begin{array}{l}(0.8 \\
9)\end{array}$ \\
\hline
\end{tabular}

$\mathrm{N}=210$. Composite Reliabilities are presented on the diagonal. $* \mathrm{p}<0.01 ; * \mathrm{p}<0.05$

Table 2. Inter-correlations among QWL subscales and Happiness

\begin{tabular}{|c|c|c|c|c|c|c|c|}
\hline Variable & Mean & 1 & 2 & 3 & 4 & 5 & 6 \\
\hline $\begin{array}{l}\text { 1. Happiness at } \\
\text { Work }\end{array}$ & 4.20 & & & & & & \\
\hline $\begin{array}{l}\text { 2. General Well- } \\
\text { Being (GWB) }\end{array}$ & 4.57 & $.601 *$ & & & & & \\
\hline $\begin{array}{l}\text { 3. Home-Work } \\
\text { Interface (HWI) }\end{array}$ & 3.81 & $.420 * *$ & $.635^{*}$ & & & & \\
\hline $\begin{array}{l}\text { 4. Job and } \\
\text { Career } \\
\text { Satisfaction } \\
\text { (JCS) }\end{array}$ & 4.13 & $.590^{*}$ & $.520^{*}$ & $.495^{*}$ & & & \\
\hline $\begin{array}{l}\text { 5. Control at } \\
\text { Work (CAW) }\end{array}$ & 4.17 & $.411^{*}$ & $.360^{*}$ & $.409 * *$ & $.618^{*}$ & & \\
\hline $\begin{array}{l}6 . \text { Working } \\
\text { Conditions } \\
\text { (WCS) }\end{array}$ & 4.29 & $.486^{*}$ & $.615^{*}$ & $.500 *$ & $.476^{*}$ & $.366 * *$ & \\
\hline $\begin{array}{l}\text { 7. Stress at } \\
\text { Work (SAW) }\end{array}$ & 4.02 & $-.67 *$ & $-0.230 * *$ & $0.196 * *$ & $-0.561 *$ & $-0.254 *$ & $-0.339^{*}$ \\
\hline
\end{tabular}

Table 3 shows the standardized regression estimates to examine the influence of six components of QWL on happiness at work. The level of significance is based on CR (critical ratio) of the regression estimates, in SPSS AMOS (Biswas and Bhatnagar 2013).
Therefore, it can be noted that hypothesis 3 is rejected as the CR is below 2.58 (homework interface $\rightarrow$ happiness at work was not significant). General well-being and job and career satisfaction regress significantly and positively on happiness at work 
QUA II IIY

DIFSIFAIDCE

(standardized

standardized $\beta=0.311, \quad \mathrm{CR}=3.22$; $\beta=0.363, \quad C R=3.33$

respectively). Therefore, hypotheses 2 and 4 are accepted. Happiness at work was influence by working condition also (standardized $\beta=0.213, \mathrm{CR}=2.78$ ) however, the least infleunce was shown by control at work (standardized $\beta=161, \quad \mathrm{CR}=3.11$ ), providing support for hypothesis 5 and 6 .

Similarly, stress at work also impacts the happiness at work, result supports H7.

The five components of QWL explained 60 percent of variance in happiness at work (figure 1). Hence, all except 'home-work interface', were found to be significant predictors of happiness among millinnials at work.

Table 3. Regression Estimates

\begin{tabular}{|l|l|l|l|l|l|}
\hline \multirow{2}{*}{ Model } & \multicolumn{2}{|l|}{$\begin{array}{l}\text { Unstandardized } \\
\text { Coefficients }\end{array}$} & \multicolumn{2}{l|}{$\begin{array}{l}\text { Standardized } \\
\text { Coefficients }\end{array}$} & \multirow{2}{*}{} \\
\cline { 2 - 5 } & $\boldsymbol{\beta}$ & $\begin{array}{l}\text { Standard } \\
\text { Error }\end{array}$ & $\boldsymbol{\beta}$ & $\mathbf{C R}$ & \\
\hline General Well-Being (GWB) & 0.216 & 0.067 & 0.311 & 3.22 & H2 ACCEPTED \\
\hline Home-Work Interface (HWI) & 0.066 & 0.037 & 0.161 & 1.79 & H3 REJECTED \\
\hline $\begin{array}{l}\text { Job and Career Satisfaction } \\
\text { (JCS) }\end{array}$ & 0.211 & 0.063 & 0.363 & 3.33 & H4 ACCEPTED \\
\hline Control at Work (CAW) & 0.086 & 0.046 & 0.161 & 3.11 & H5 ACCEPTED \\
\hline Working Conditions (WCS) & 0.114 & 0.048 & 0.213 & 2.78 & H6 ACCEPTED \\
\hline Stress at Work (SAW) & 0.145 & 0.025 & 0.464 & 5.75 & H7 ACCEPTED \\
\hline
\end{tabular}

Note: N=210; dependent variable- Happiness at work. The CR is recommended to be beyond +2.58 significant at $p<0.05$ level.

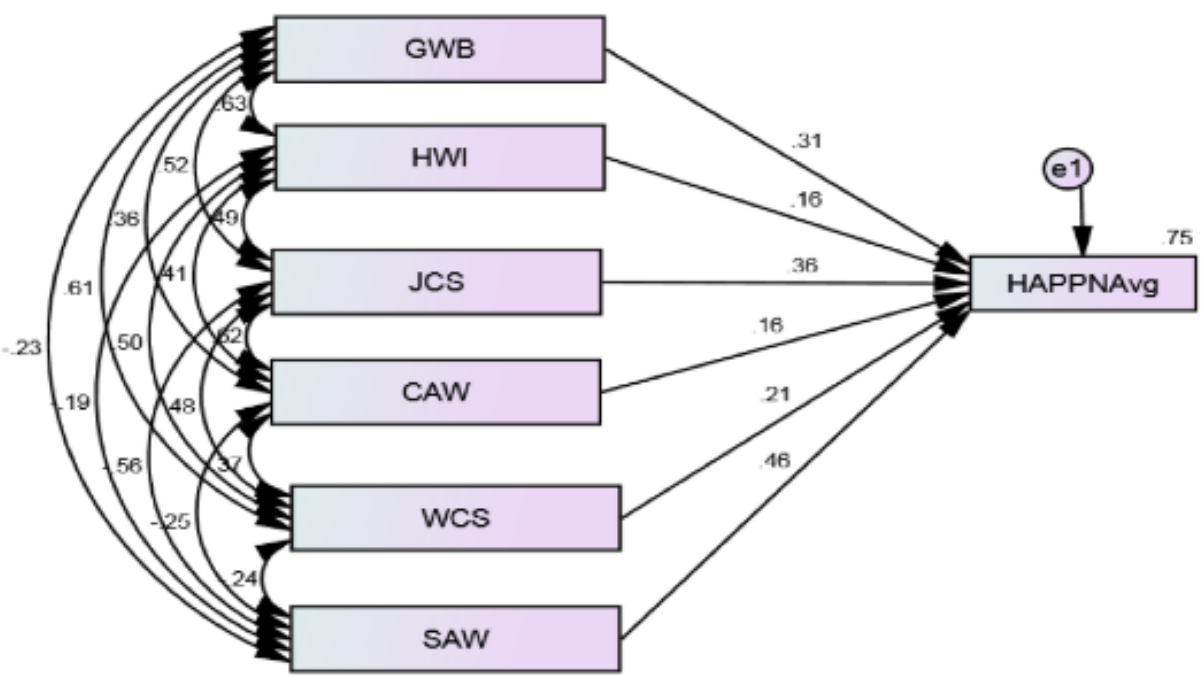

Figure 1. Regression estimates

In the response to the questions on what makes them happy at work, 47 percent of respondents mentioned 'recognition and appreciation', as an important factor at work, 
while 23 percent of the respondents said they like the work environment. Others indicated 'flexibility', 'rewards' and 'work itself' as few factors at workplace that makes them happy and engaged at work.

This category of workforce, the millennial have diverse expectations from work unlike, the old mature employees, which calls for special attention from the managers to understand their nature and provide them appropriate recognition and motivates them (Meola, 2016). Milleniial prefer flexibility at work, so that there is a proper work life balance.

The findings evidently suggest that the quality work environment has a great impact on the happiness levels of the employees. Particularly for the millennial employees, general well-being and career satisfaction are the most significant predictors of their happiness and engagement at work. There can be other factors which influence HAW for example, leadership has been found to impact employee's happiness at work (SalasVallina and Alegre, 2018; Joo \& Lee, 2017; De Waal, 2018) and organizational citizenship behaviour (Salas-Vallina and Fernandez, 2017).

A happy and healthy employee will give better output, make good decisions and positively contribute to the organizational goals. An assured good quality of work life will not only attract young and new talent but also retain the existing experienced talent. The study has explored the complex linkages between quality of work life, quality of life and happiness at work of millennial employees. The findings clearly suggest that all the three constructs of the study closely related. By knowing the predictors of millennial's happiness at work, organizations would identify ways and means to improve the approach and minimizing the adverse impact of changes in work environments pertaining to happiness at work. Improvement in QWL is a source of numerous gains. It might lead to improved positive feelings towards one's self (greater self-esteem), towards one's job (improved job satisfaction and involvement), and towards the organization (strong organizational commitment). It also results in building up of physically and psychologically healthier, productive, engaged and motivated employees.

\section{Conclusion}

Millennial employees are ambitious and look for improvements in the ways organization work and being young they are more receptive to change. The findings of this study would help the banking industry of Saudi Arabia to review the level of prevailing QWL, QoL and HAW, and to enhance the same by implementing appropriate policies. A good human resource practice would encourage banking professionals to be more productive while enjoying their work. This study contributes and advances the current knowledge and literature on the subject. Findings have significantly proven that many factors in the work environment influence the happiness of employees to a large extent, however, not all factors of quality of work life have equal impact, the findings contradict the previous research that suggests happiness was significantly related with all the components of working life quality (Toulabi et al., 2013).

This study has filled the research gap in that it has studied how QWL influences HAW, which was the suggestion of Spencer (2014), to study the work related factors which influence happiness. In appraising the happiness, we cannot ignore the two important aspects: QWL and QOL, which are the essential factors to predict happiness of employees. As HAW is conditional, which means the better the QWL more will be the happiness among employees. The evaluation of QWL and HAW could help in establishment, implementation and development of programs for organizations and can affect the society at large. The 
findings suggest substantial managerial and social implications for policy design. One of the limitation of this study is the small sample size. Therefore, future studies can be conducted to test this complex relationship on other professions and sectors with large sample size.

\section{References:}

Bakker, A. B., \& Oerlemans, W. G. (2016). Momentary work happiness as a function of enduring burnout and work engagement. The Journal of psychology, 150(6), 755-778.

Buchanan, D. A., \& McCalman, J. (2018). High performance work systems: The digital experience. Routledge.

De Waal, A. (2018). Increasing organisational attractiveness: The role of the HPO and happiness at work frameworks. Journal of Organizational Effectiveness: People and Performance, 5(2), 124-141.

Diener, E., \& Diener, C. (1996). Most people are happy. Psychological science, 7(3), 181-185.

Diener, E., \& Suh, E. (1997). Measuring quality of life: Economic, social, and subjective indicators. Social indicators research, 40(1-2), 189-216.

Dunning, H., Williams, A., Abonyi, S., \& Crooks, V. (2008). A mixed method approach to quality of life research: A case study approach. Social indicators research, 85(1), 145-158.

Elizur, D., \& Shye, S. (1990). Quality of work life and its relation to quality of life. Applied Psychology, 39(3), 275-291.

Erikson, R. (1993). Descriptions of Inequality: The Swedish Approach to Welfare Research145. The quality of life, 67.

Fallowfield, L. (1990). What is quality of life. London: Souvenir, 54-7.

Fisher, C. D. (2010). Happiness at work. International journal of management reviews, 12(4), 384-412.

Gayathiri, R., Ramakrishnan, L., Babatunde, S. A., Banerjee, A., \& Islam, M. Z. (2013). Quality of work life-Linkage with job satisfaction and performance. International Journal of Business and Management Invention, 2(1), 1-8.

Gregory, A., \& Milner, S. (2009). Work-life balance: A matter of choice?. Gender, Work \& Organization, 16(1), 1-13.

Guest, D. E. (2017). Human resource management and employee well-being: Towards a new analytic framework. Human Resource Management Journal, 27(1), 22-38.

Gulyani, G., \& Sharma, T. (2018, December). Total rewards components and work happiness in new ventures: The mediating role of work engagement. In Evidence-based HRM: a Global Forum for Empirical Scholarship (Vol. 6, No. 3, pp. 255-271). Emerald Publishing Limited.

Hackman, J. R. (2009). The perils of positivity. Journal of Organizational Behavior: The International Journal of Industrial, Occupational and Organizational Psychology and Behavior, 30(2), 309-319.

Hoebel, J., Kuntz, B., Müters, S., \& Lampert, T. (2013). Subjective social status and healthrelated quality of life among adults in Germany. Results from the German General Social Survey (ALLBUS 2010). Gesundheitswesen (Bundesverband der Arzte des Offentlichen Gesundheitsdienstes (Germany)), 75(10), 643-651.

Inoguchi, T., \& Fujii, S. (2012). The quality of life in Asia: A comparison of quality of life in Asia (Vol. 1). Springer Science \& Business Media.

Joaquim Araújo de Azevedo, A., João Ferreira Custódio, M., \& Pereira Antunes Perna, F. (2013). "Are you happy here?": the relationship between quality of life and place 
attachment. Journal of Place Management and Development, 6(2), 102-119.

Joo, B. K., \& Lee, I. (2017, August). Workplace happiness: work engagement, career satisfaction, and subjective well-being. In Evidence-based HRM: A Global Forum for Empirical Scholarship (Vol. 5, No. 2, pp. 206-221). Emerald Publishing Limited.

Kalra, S. K., \& Ghosh, S. (1984). Quality of work life-a study of associated factors. Indian Journal of Social Work, 45(3), 341-349.

Kashdan, T. B., Biswas-Diener, R., \& King, L. A. (2008). Reconsidering happiness: The costs of distinguishing between hedonics and eudaimonia. The Journal of Positive Psychology, 3(4), 219-233.

Kim, T., Karatepe, O. M., Lee, G., Lee, S., Hur, K., \& Xijing, C. (2017). Does hotel employees' quality of work life mediate the effect of psychological capital on job outcomes?. International Journal of Contemporary Hospitality Management, 29(6), 16381657.

Lyubomirsky, S., Sheldon, K. M., \& Schkade, D. (2005). Pursuing happiness: The architecture of sustainable change. Review of general psychology, 9(2), 111-131.

ManpowerGroup (Firm). (2016). Millennial careers: 2020 vision: facts, figures and practical advice from workforce experts.

Marques, J. F. (2017). Oh, what happiness! Finding joy and purpose through work. Development and Learning in Organizations: An International Journal, 31(3), 1-3.

Mazuki, R., Samah, A. A., Omar, S. Z., Zawawi, D., Idris, K., D’Silva, J. L., ... \& Kamaruddin, N. A. (2017). Towards Developing a Framework on Happiness and Productivity among Personnel in Institution of Higher Learning. International Journal of Academic Research in Business and Social Sciences, 7(7), 269-278.

Michalos, A. (2006), “Conceptual and philosophical foundations", Social Indicators Research, Vol. 76 No. 53, pp. 163-87.

Mirvis, P. H., \& Lawler III, E. E. (1984). Accounting for the quality of work life. Journal of Organizational Behavior, 5(3), 197-212.

Moccia, S. (2016). Happiness at work. Papeles del Psicólogo, 37(2), 143-151.

Narehan, H., Hairunnisa, M., Norfadzillah, R. A., \& Freziamella, L. (2014). The effect of quality of work life (QWL) programs on quality of life (QOL) among employees at multinational companies in Malaysia. Procedia-Social and Behavioral Sciences, 112, 24-34.

Nayak, T., \& Sahoo, C. K. (2015). Quality of work life and organizational performance: The mediating role of employee commitment. Journal of Health Management, 17(3), 263-273.

Noll, H. H. (2002). Towards a European system of social indicators: Theoretical framework and system architecture. Social indicators research, 58(1-3), 47-87.

Pryce-Jones, J., \& Lindsay, J. (2014). What happiness at work is and how to use it. Industrial and Commercial Training, 46(3), 130-134.

Sahni, J. (2017). Exploring What Constitutes'quality'in Quality of Work Life For Female Employees. International Journal For Quality Research, 11(4).

Sahni, J. (2019). Role of quality of work life in determining employee engagement and organizational commitment in telecom industry. International Journal for Quality Research, 13(2).

Salas-Vallina, A., \& Alegre, J. (2018). Unselfish leaders? Understanding the role of altruistic leadership and organizational learning on happiness at work (HAW). Leadership \& Organization Development Journal, 39(5), 633-649.

Salas-Vallina, A., Alegre, J., \& Fernandez, R. (2017). Happiness at work and organisational citizenship behaviour: is organisational learning a missing link?. International Journal of Manpower, 38(3), 470-488. 
QUA II II Y

Schaufeli, W.B. and Bakker, A.B.(2004a), "Work engagement and the measurement of a

Schaufeli, W.B. and Bakker, A.B. (2004a), "Work engagement and the measurement of a concept", Gedrag-en-Organisatie, Vol. 17, pp. 89-112.

Seashore, S. E. (1975). Defining and measuring the quality of working life. The quality of working life, 1, 105-118.

Sirgy, M. J., Efraty, D., Siegel, P., \& Lee, D. J. (2001). A new measure of quality of work life (QWL) based on need satisfaction and spillover theories. Social indicators research, 55(3), 241-302.

Sirgy, M. J., Michalos, A. C., Ferriss, A. L., Easterlin, R. A., Patrick, D., \&Pavot, W. (2006). The Qualityof-Life (QOL) Research Movement : Past, Present and Future.Social Indicator Research , 343-466.

Sousa Gomes, M. C., Luís Rocha Pinto, M., \& Gomes dos Santos, G. (2010). Quality of life: a reappraisal. International journal of sociology and social policy, 30(9/10), 559-580.

Spencer, D. A. (2014). Conceptualising work in economics: Negating a disutility. Kyklos, 67(2), 280-294.

Tay, L., Kuykendall, L., \& Diener, E. (2015). Satisfaction and happiness-the bright side of quality of life. In Global handbook of quality of life (pp. 839-853). Springer, Dordrecht.

Tideman, S. G. (2016). Gross national happiness: lessons for sustainability leadership. South Asian Journal of Global Business Research, 5(2), 190-213.

Toulabi, Z., Raoufi, M., \& Allahpourashraf, Y. (2013). The relationship between teachers' happiness and quality of working life. Procedia-Social and Behavioral Sciences, 84, 691695.

Ugwu, F. O., Onyishi, I. E., \& Rodríguez-Sánchez, A. M. (2014). Linking organizational trust with employee engagement: The role of psychological empowerment. Personnel Review, 43(3), 377-400.

Ura, K., \& Galay, K. (2004). Gross national happiness and development. Thimpu: The Centre for Buthan Studies.

Veenhoven, R. (1991). Is happiness relative?. Social indicators research, 24(1), 1-34.

Veenhoven, R. (2001). Quality-of-Life and Happiness: not quite the same. Retrieved from http://hdl.handle.net/1765/8753

Walton, R. (1980). Quality of work life activities: A research agenda. Professional Psychology, 11(3), 484.

Walton, R. E. (1973). Quality of working life: what is it. Sloan management review, 15(1), 1121.

Wu, L. H., \& Tsay, R. M. (2018). The Search for Happiness: Work Experiences and Quality of Life of Older Taiwanese Men. Social Indicators Research, 136(3), 1031-1051.

Xanthopoulou, D., Bakker, A. B., \& Ilies, R. (2012). Everyday working life: Explaining within-person fluctuations in employee well-being. Human Relations, 65, 1051- 1069. doi: $10.1177 / 0018726712451283$

\section{Jolly Sahni}

Prince Sultan University,

Riyadh,

Saudi Arbia

jsahni@psu.edu.sa 